Proc. Estonian Acad. Sci. Geol., 2001, 50, 2, 95-113

\title{
MIDDLE ARTINSKIAN (EARLY PERMIAN) ECOLOGICAL EVENT: A CASE STUDY OF THE URALS AND NORTHERN TIMAN
}

\author{
Olga L. KOSSOVAYA ${ }^{\mathrm{a}}$, Ekaterina A. GUSEVA $^{\mathrm{a}}$, Alexander E. LUKIN ${ }^{\mathrm{b}}$, \\ and Andrei V. ZHURAVLEV ${ }^{\mathrm{a}}$ \\ a All-Russian Scientific Research Geological Institute, Sredny 74, St. Petersburg 199026, Russia; \\ vsegei@mail.wplus.net \\ b Institute of Geological Sciences, Ukrainian Academy of Sciences, ul. Tchkalova 56, Kiev, \\ Ukraine
}

Received 8 April 1999, in revised form 28 June 2000

\begin{abstract}
Biotic and abiotic changes established in the middle Artinskian of several sections of the northern Timan and the western slope of the Central Urals are discussed. Data on the distribution of corals, composition of the biota as a whole, palaeotemperature and microfacies changes are presented for the first time. The determination of the stratigraphic levels is based on the new and revised biostratigraphic data. The palaeotemperature decline coincides with the maximal flooding surface and is considered as a possible cause of the ecological event triggering the turnover or extinction of many faunal groups. The event level was recognized in the coeval deposits along the Pangea shelves.
\end{abstract}

Key words: middle Artinskian event, biota turnover, sequence stratigraphy, oxygen and carbon isotopes.

\section{INTRODUCTION}

The end of the Early Permian was a time of distinctive abiotic and biotic changes, previously discussed in Gorsky et al. (1984), Beauchamp et al. (1987, 1989), Beauchamp \& Theriault (1994), Kossovaya (1994), and Leven et al. (1996). Selective disappearance and replacement of different faunal groups, especially great changes in rugose corals, have been recorded from the Late Sakmarian to Late Artinskian.

The goal of this paper is to show the evolution of rugose corals before and after the mid-Artinskian event and possible ecological triggers for the biotic crisis within the Urals-Cordillera-Arctic province (name of the province after Fedorowski 1986a). Earlier data on the pre-crisis evolution of rugose corals 
(Kossovaya 1993, 1994, 1996, 1997) were considered in order to assess the range and scale of coral turnover and extinction. Abiotic causes of the crisis are interpreted based on comparative analysis of the biostratigraphic, sedimentological, microfacies, and isotopic data.

\section{MATERIALS AND METHODS}

For this study several Artinskian sections were investigated in the northern part of the Central Urals, including the Most and Karpikha sections (Fig. 1). Additionally, the Irgina section (Fig. 1) of the lowermost Kungurian, and the Lower Permian sections on the eastern slope of the northern Timan (northeastern part of the Russian Platform; Fig. 2) were studied. Both regions correspond to the northeastern marginal basin of the Pangea palaeocontinent.

New data on ${ }^{18} \mathrm{O}$ and ${ }^{13} \mathrm{C}$ from brachiopod shell carbonates, $\mathrm{Ca} / \mathrm{Mg}$ ratio, and microfacies analyses were used to determine the ecological nature of the changes within the middle Artinskian. In addition to microfacies analysis, the insoluble residues of samples consisting of the silicified micro- and, partly, macrofossils were examined. The data received by both methods allowed us to reconstruct the biotic changes near the crisis level.

\section{BIOSTRATIGRAPHIC DATA}

Biostratigraphic subdivision of the Lower Permian of the Urals was established long ago. Recent changes in the Artinskian part of it are shown in Fig. 3.

The data obtained have been used for creating and improving the ostracode and coral zonal charts. Considering the data by E. Guseva (in Gorsky et al. 1984), we could redetermine the age of the deposits in the Upper Artinskian portion (Sargian Substage) of the Most and Karpikha sections (Figs. 1, 3). According to our findings, the event level coincides with the base of the Bairdia aculeata ostracode Zone in the carbonate-siliciclastic rocks of the Sargian Substage or with the upper boundary of the Eoparafusulina lutugini-Pseudofusulina juresanensis fusulinid Zone in the shallow reef deposits of the Irginian Substage. The post-crisis ostracode assemblage, appearing at the Lower/Upper Artinskian boundary in the Most and Karpikha sections, includes Healdia arcuata Coryell \& Osario, Bairdia magna Kotsch., B. cf. B. kaschewarovae Mart., B. perlonga Kash., and B. aculeata Coope. The coral community of this part of the sections, considered as holdover type I (Figs. 1,4), contains Soshkineophyllum artiense Soshk., Ufimia carbonaria Stuck., Ufimia sp. 1, Paralleynia permiana Soshk., ? Lophocarinophyllum ilitshense Soshk., Cyathocarinia multituberculata Soshk., Cyathaxonia ex gr. C. cornu Mich., C. dobrolyubovae Sim., Pseudo- 


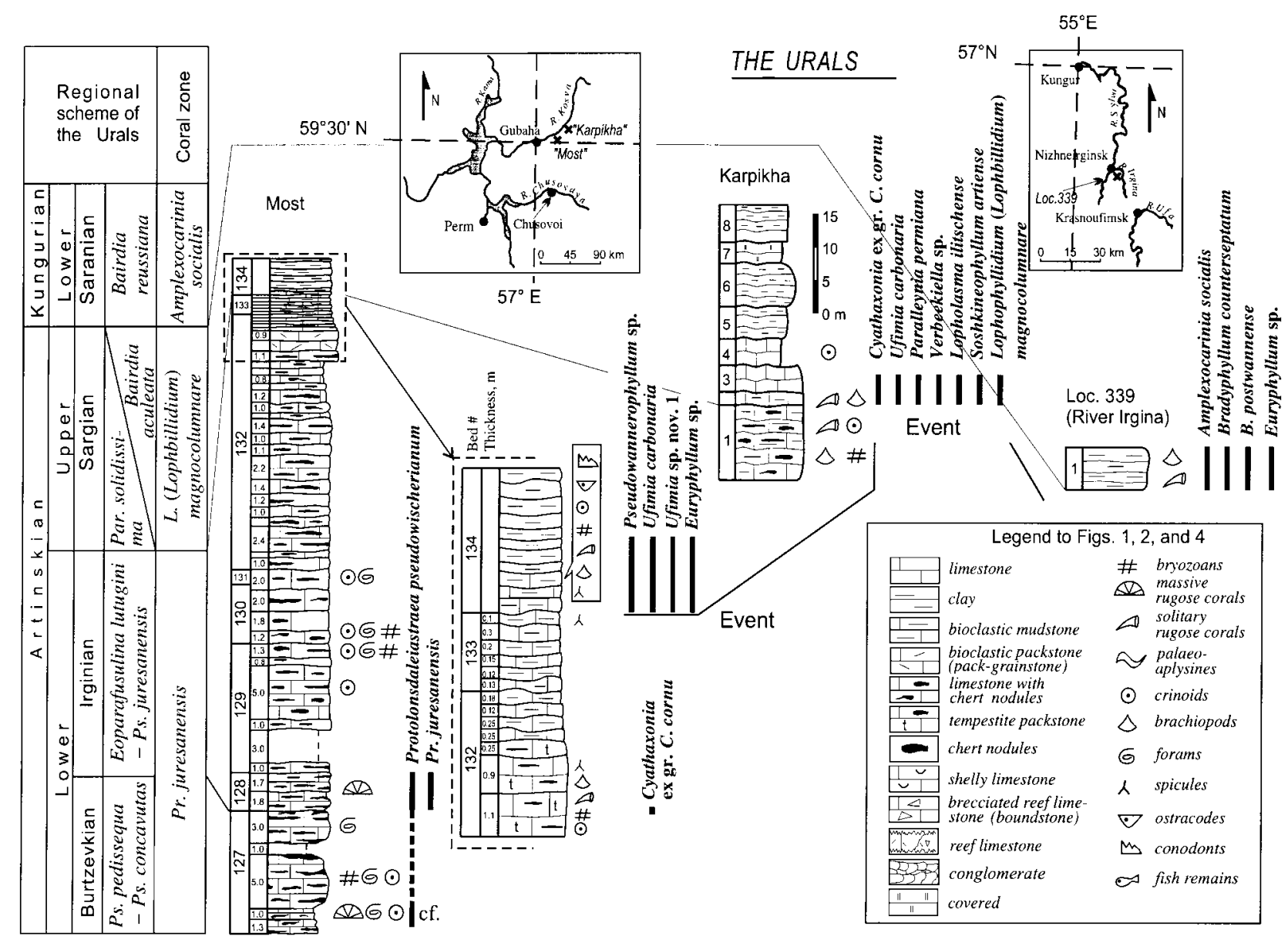

Fig. 1. Correlation of the Central Urals sections (Most, Karpikha, and Irgina). 


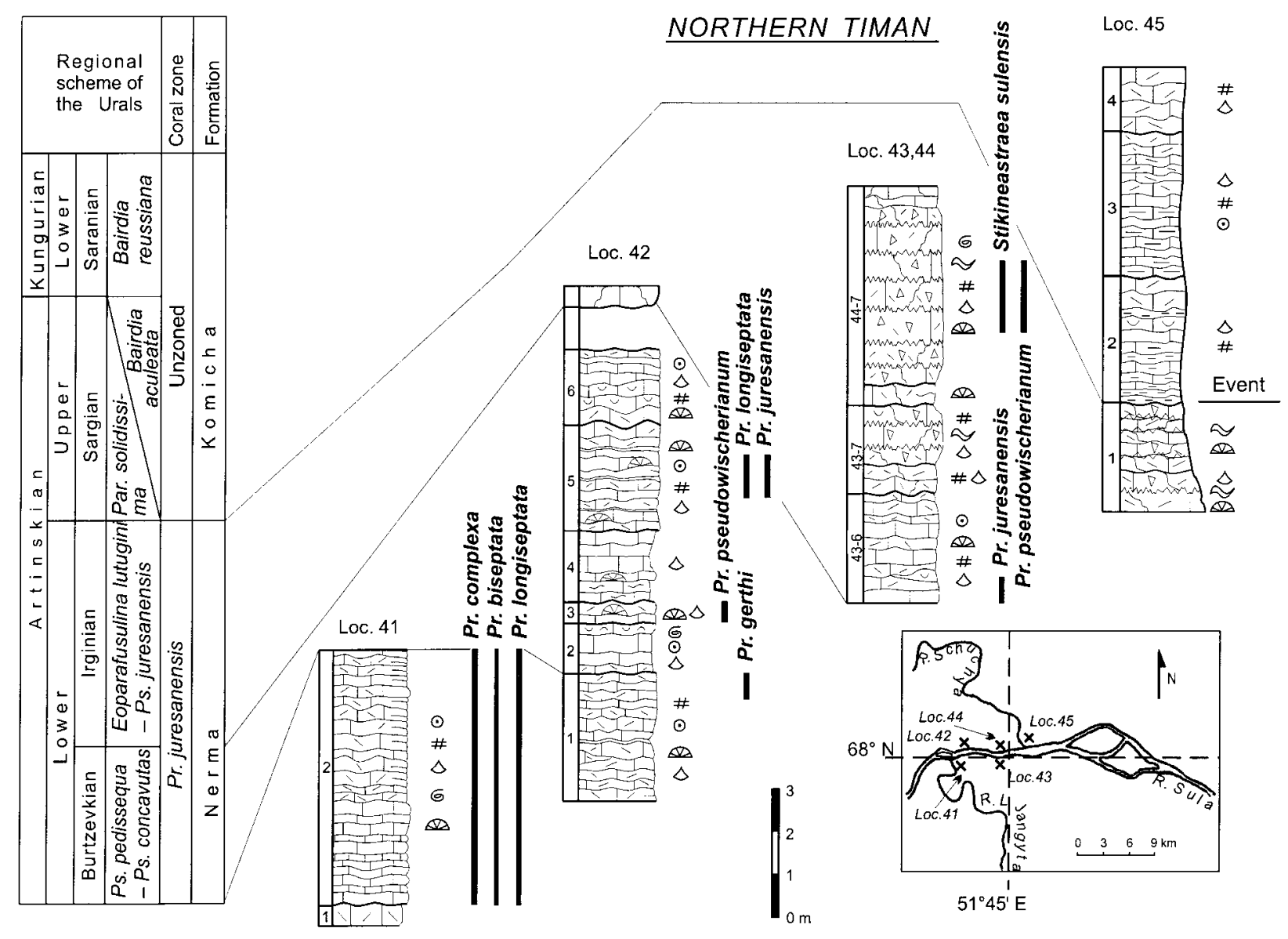

Fig. 2. Correlation of the Sula River localities (Sula section) of the northern Timan. For legend see Fig. 1. 


\begin{tabular}{|c|c|c|c|c|c|c|c|c|c|}
\hline \multicolumn{4}{|c|}{$\begin{array}{c}\text { Regional scheme } \\
\text { of the Urals } \\
\text { (Antsygin et al. 1993) }\end{array}$} & \multicolumn{2}{|c|}{ 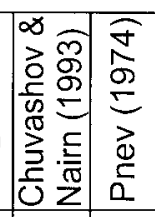 } & \multicolumn{2}{|c|}{$\begin{array}{c}\text { Chuvashov } \\
\text { et al. (1996), } \\
\text { Chuvashov } \\
(1997)\end{array}$} & \multicolumn{2}{|c|}{ Authors' data } \\
\hline 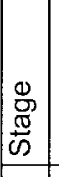 & 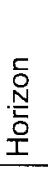 & 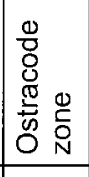 & 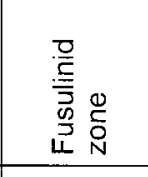 & 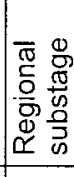 & 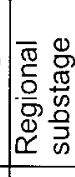 & 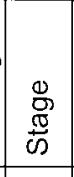 & 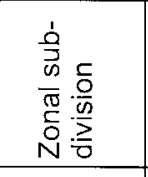 & 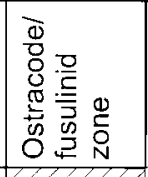 & 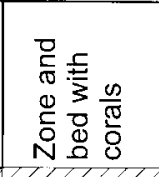 \\
\hline 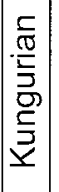 & 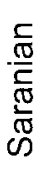 & 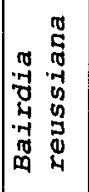 & & & & 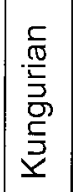 & 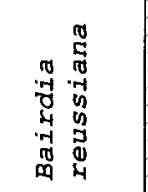 & 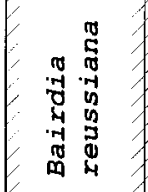 & 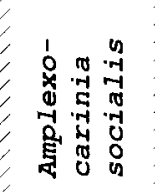 \\
\hline \multirow{3}{*}{$\begin{array}{l}= \\
0 \\
- \\
x \\
0\end{array}$} & . & \multirow{3}{*}{ 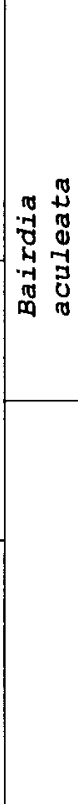 } & 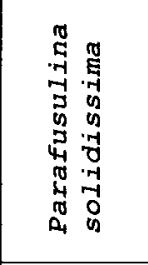 & & & \multirow{3}{*}{ 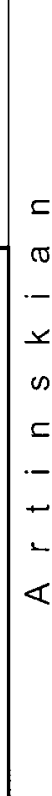 } & 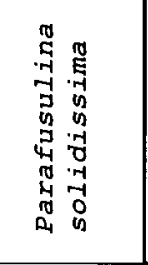 & 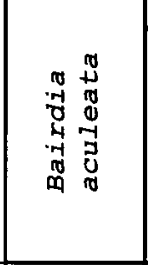 & 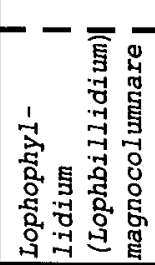 \\
\hline & 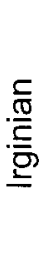 & & 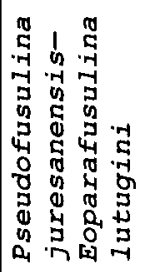 & \multirow{2}{*}{ 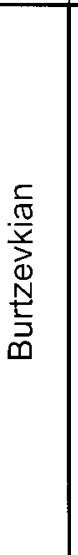 } & \multirow{2}{*}{$\mid \begin{array}{l}\frac{c}{\sqrt{0}} \\
\frac{\pi}{4} \\
\frac{\pi}{\pi} \\
\frac{\pi}{<}\end{array}$} & & 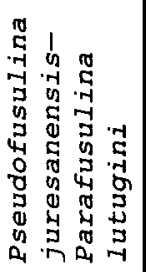 & 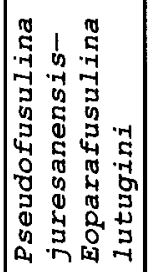 & \multirow{2}{*}{ 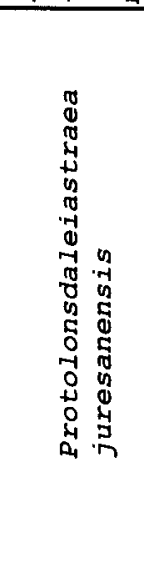 } \\
\hline & 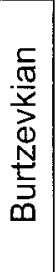 & & 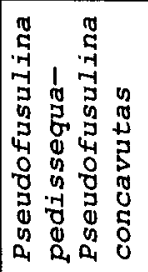 & & & & 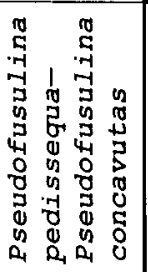 & 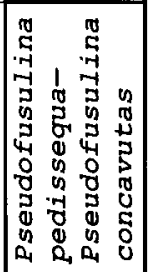 & \\
\hline
\end{tabular}

Fig. 3. Comparison of the biostratigraphic schemes of the Central Urals based mainly on the Karpikha, Most, and Irgina sections. Subdivisions of the Most and Karpikha sections framed with the solid line. Subdivisions of the Irgina sections framed with diagonal stripes. 


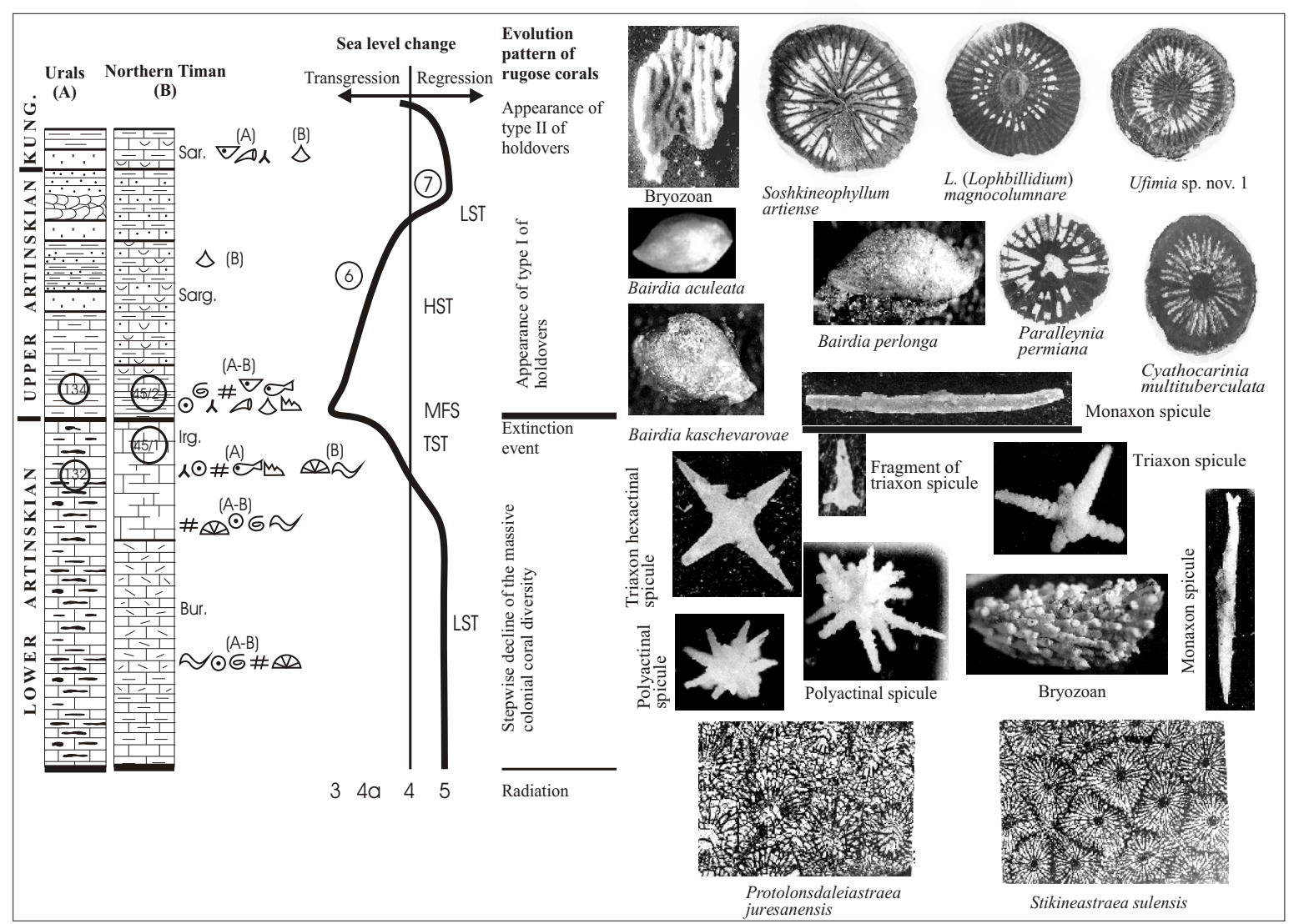

Fig. 4. Correlation of the sequence-stratigraphic subdivisions of the Artinskian and lowermost Kungurian deposits of the Central Urals and northern Timan, and biotic composition: 3 , deep shelf margin facies; 4 , foreslope facies of carbonate platform; 4a, tempestites; 5 , organic reef of platform margin; 6, turbidites; 7, open marine platform facies with terrigenous fans. Abbreviations: Sar., Saranian; Sarg., Sargian; Irg., Irginian; Bur., Burtzevkian; LST, lowstand system tract; HST, highstand system tract; MFS, maximal flooding surface; TST, transgressive system tract. For legend see Fig. 1. 
wannerophyllum sp. 1, and Verbeekiella sp., together with the Upper Leonardian species Lophophyllidium (Lophbillidium) magnocolumnare (Fedor.), and $L$. (L.) cyathaxoniforme Fedor. The pre-crisis assemblage consists of massive colonial corals, such as Protolonsdaleiastraea juresanensis Dobr. and Stikineastraea sulensis Koss., occurring in Palaeoaplysina-coral buildups of the Sula River section (northern Timan, localities 43-45, Fig. 2). Eoparafusulina lutugini (Grozd.) has been recorded by Barkhatova (1970) in the upper part of locality 44. The post-crisis assemblage, occurring in the packstones and wackestones intercalated with thin clay layers (locality 45), contains the brachiopods Sowerbina sulaensis Barch., Linoproductus ex gr. L. cora (Orb.), Spiriferella timanica Barch., and Spiriferella polaris Barch. (Goreva et al. 1997).

The ostracode assemblage found in the lower part of the Saranian Substage of the Kungurian Stage in the Irgina River section includes species of the Bairdia reussiana Zone, such as Paraparchites kamajicus Guss., P. sylvaensis Guss., Healdia distributa Guss., Bairdia cultrataeformis Guss., and B. reussiana Guss. The rugose coral assemblage is poor, containing Amplexocarinia socialis Sosh. (dominant), Amplexocarinia sp., Euryphyllum sp. 1, Euryphyllum sp., Bradyphyllum aff. postwannense Fedor., Lytvolasma sp., Bradyphyllum aff. counterseptatum Fedor., and Euryphyllum aff. profundum Fedor.

Only a few occurrences of the coeval corals are known in the northern shelves of the Pangea palaeocontinent. Euryphyllum sp. A and Euryphyllum sp. B, which show a wide range of intraspecific and interspecific morphological variations, are known from unit 1 at the base of the Kapp Starostin Formation of Spitsbergen (Ezaki \& Kawamura 1992; Ezaki 1997).

\section{SEQUENCE STRATIGRAPHY AND FACIES}

The pre-event (Burtzevkian-Irginian) interval in the Most section (the Central Urals) is represented by the carbonate facies of the upper part of the foreslope (Wilson 1980). Two sequences are recognized in the Artinskian deposits (Fig. 4).

The lowstand system tract is represented by the succession from the reef facies to crinoid-foraminiferal packstones of the inner platform foreslope. In the Most section the reef facies of the platform margin (facies 5) is constituted by the coral-Palaeoaplysina-algal boundstone framework or algal-coral-Palaeoaplysina packstones (bed 127, Fig. 1). This interval is determined as the Pseudofusulina pedissequa-Ps. concavutas fusulinid Zone, or the lower part of the Protolonsdaleiastraea juresanensis coral Zone (Figs. 3, 5; Kossovaya 1996), which corresponds to the Burtzevkian Substage (Chuvashov \& Nairn 1993). Corals are represented by Protolonsdaleiastraea juresanensis (Dobr.) and Pr. pseudowischerianum (Porf.).

The foreslope facies of the carbonate platform, observed in the Most section in bed 128 (Fig. 1) is formed by wacke-packstone composed of bryozoans, crinoids, colonial corals (sporadically), and Palaeoaplysina debris (Fig. 4; facies 4 by 


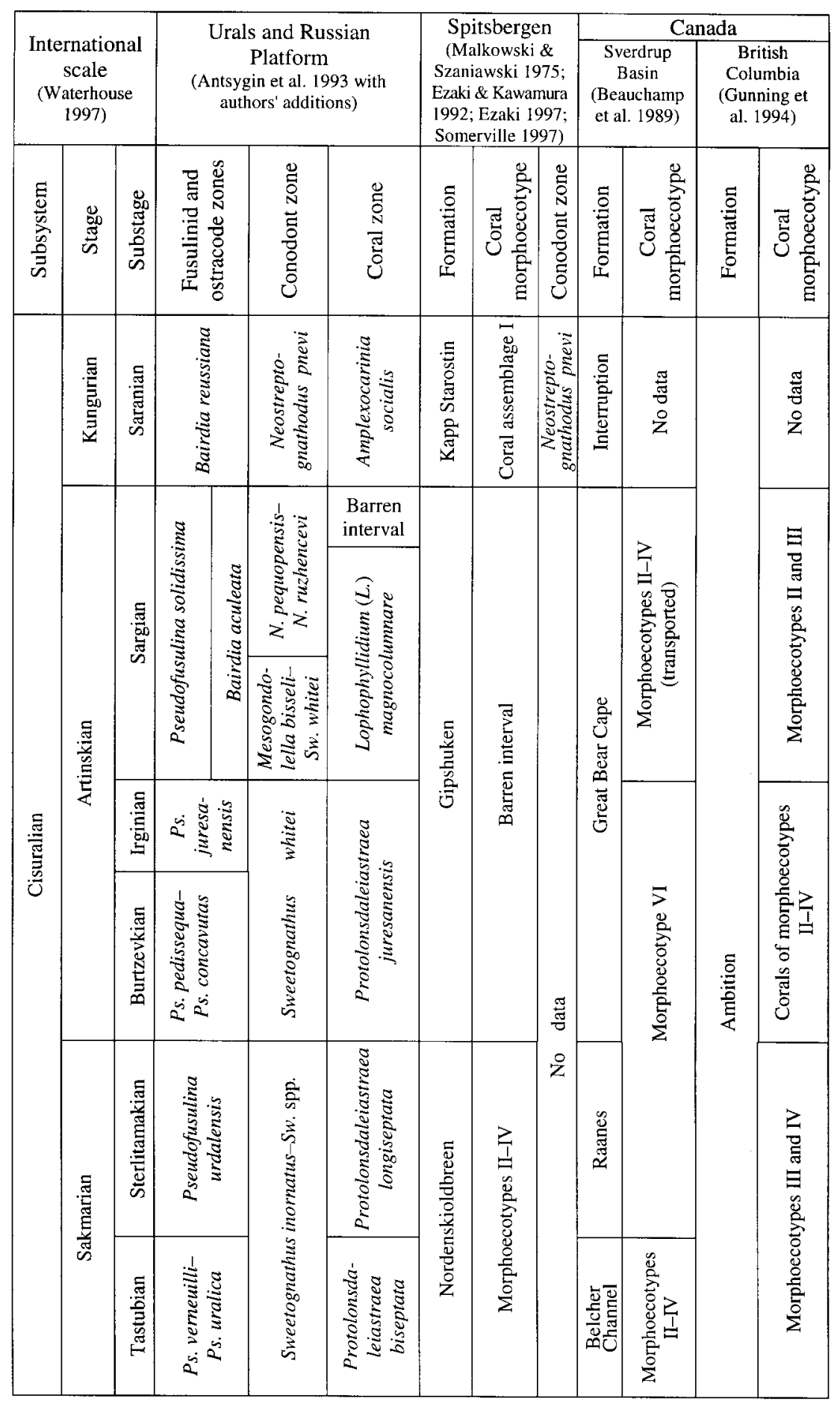

Fig. 5. Correlation chart of the Sakmarian-Artinskian deposits of the northern and eastern shelves of the Pangea palaeocontinent. 
Wilson 1980). The age was determined by the occurrence of Pseudofusulina juresanensis - one of the fusulinid zonal species of the Irginian Substage.

Coeval deposits (analogues of facies belts 4 and 5) form the lower part of the Nerma Formation of the northern Timan sections. In the Sula River section they are represented by crinoid-foraminiferal packstone interbedded with foraminiferal grainstone bearing numerous colonial corals (Fig. 2, locality 42, beds 2-5). The age of these sediments is dated by the co-occurrence of the corals Protolonsdaleiastraea juresanensis and Pr. gerthi, and the fusulinids Pseudofusulina urdalensis and Ps. concavutas (fusulinids identified by Barkhatova 1970).

In the Most section, tempestites of the lower part of the foreslope are represented by wavy-bedded wacke-packstones with numerous sponge spicules (facies 4a) and are considered as the transgressive system tract. The spicule association includes monaxon, triaxon, and tetraxon spicules. They were found together with crinoids, brachiopods, and bryozoan debris (samples 132-1 and 132-2 from bed 132). Fossil fragments often form thin parallel layers. Clasts of bryozoans, crinoids, tabulate corals, and rare fusulinids are scattered on wavy bed surfaces. In the upper part of this unit, the abundance of spicules increases and the monaxon spicules dominate (sample 132-4). Only one specimen of deepwater Cyathaxonia sp. has been found in this part of the section. The age of this unit corresponds to the Eoparafusulina lutugini-Pseudofusulina juresanensis fusulinid Zone of the Irginian Substage. The beginning of the transgression is marked by tempestites which contain the deeper nektoplanktic fossils, such as fish remains, conodont fragments, and rare radiolarians, also abundant bryozoan debris. The coeval deposits of the Sula River section are represented by Palaeoaplysina-coral buildups with Stikineastraea sulensis Koss., Protolonsdaleiastraea juresanensis Dobr. (Kossovaya 1997), and rare Eoparafusulina lutugini (Barkhatova 1970) in the upper part of the Nerma Formation (Fig. 2, localities 43, 44).

The overlying deposits (from the base of layer 134) are characterized in the Most and Karpikha sections by the alternation of thin-bedded green-grey bioclastic packstone, mudstone, and siltstone which are considered as the highstand system tract. Packstone contains monaxon spicules, ostracode debris, conodonts (Neostreptognathodus sp.), some bryozoans, small crinoid fragments, and fish remains. Sometimes the monaxon spicules form spiculites. In this case spicules show subparallel orientation. A new post-crisis fossil community contains bryozoans, well-preserved small solitary corals, and brachiopods. This unit corresponds to the Bairdia aculeata Zone (Sargian Substage) and Lophophyllidium (Lophbillidium) magnocolumnare coral beds (Fig. 1). Cyathaxonia and Cyathocarinia are considered as the indicators of deep-water facies. Fish remains belonging to nektic Acanthodus sp. and Palaeonisci sp. were found here (identified by A. O. Ivanov). The base of bed 134 (sample 134-1) is interpreted as the maximum flooding surface according to the microfacies changes and appearance of the deep-water coral assemblage, pelagic, and neritic 
fauna. The development of transgression is reflected in the Sula River section by abrupt onlap of the thin layer of clay and wackstone of the Komicha Formation on the Palaeoaplysina-coral reef boundstone of the upper part of the Nerma Formation (Fig. 2, locality 45).

The diversity of benthic and nektoplanktic fauna decreases gradually towards the Upper Artinskian turbidites formation, followed by coarse-grained clastic sediments represented by conglomerates and sandstones of terrigenous fans (Rassolnyi section, the Urals). The latter sediments are considered to be formed in the lowstand system tract.

Proceeding from the microfacies and biota composition, the sea level change may be regarded as a gradual increase in transgression until the maximal flooding surface (the level of coral turnover, Fig. 4). It is followed by the filling of the basin with sediments of terrigenous fans.

Coeval transgressive sedimentological changes occur in the upper part of the Gipshuken Formation (West Spitsbergen), where brachiopods, bryozoans, and sponge spicules give evidence of the more open marine influx (Keilen 1992). The Great Bear Cape Formation (Sverdrup Basin) comprises a shallowing succession of bioclastic carbonates with turned over colonial corals and reworked fusulinids, interpreted as tempestites resulting from high-energy events on an open, wave-swept shelf (Beauchamp \& Theriault 1994). The event level, which is mostly based on transition to colder temperature, approximately coincides with the middle part of the Great Bear Cape Formation (Beauchamp et al. 1989; Beauchamp \& Theriault 1994) (Fig. 5).

The appearance of rugose holdover assemblage II in the earliest Kungurian (Irgina section, Fig. 1) during an ingression seems to be a result of the next transgression (new sequence) (Fig. 2). The Lower Kungurian deposits (Saranian Substage) in the Irgina River section were formed in the interreef environment resulting from ingression. These are represented by mudstone with ostracodes and a taxonomically impoverished coral assemblage. The beginning of a significant sea level rise was noted also in the Voringen Member of the lowermost Kapp Starostin Formation, West Spitsbergen (Keilen 1992).

\section{RESULTS OF OXYGEN AND CARBON ISOTOPIC ANALYSIS}

The analysis of ${ }^{18} \mathrm{O}$ and ${ }^{13} \mathrm{C}$ isotopes was performed with calcite taken from the shells of brachiopods found in the Sula River section. The $\delta^{13} \mathrm{C}$ values increase from $+3.1 \%$ o to $+3.5 \%$ o from sample $42 / 1$ to $45 / 2$ in this section. The fluctuation of oxygen isotope ratio within the same stratigraphical interval has the same short-term trend from $-8.5 \%$ to $-8 \%$ PDB with a further decrease to $-8.2 \%$ o (sample 47/1; Goreva et al. 1997). The increase in $\delta^{18} \mathrm{O}$ values is interpreted as a result of the temperature fall at the event level. The palaeotemperature data based on the $\mathrm{Ca} / \mathrm{Mg}$ ratio show the average value between $+15^{\circ} \mathrm{C}$ and 
$+17^{\circ} \mathrm{C}$ in the northern Timan section (samples $45 / 1$ and $45 / 2$ ) and $+19^{\circ} \mathrm{C}$ in the Central Urals section (sample 134/1) (Fig. 4). A temperature of $+13^{\circ} \mathrm{C}$ in the Upper Carboniferous-Permian, determined from primary carbonates in the Sverdrup Basin of the Canadian Arctic, was interpreted as characterizing deepwater sediments (Beauchamp et al. 1987). The maximum temperature in the Late Sakmarian approximately coincided with the sea level drop, while the maximum flooding coincided with the temperature decline at the mid-Artinskian event level in the Central Urals and northern Timan basins.

\section{CHANGES IN FAUNA AND FLORA}

Taxonomic diversity of different faunal groups within the uppermost Sakmarian-lower Artinskian is well studied (Bogoslovskaya 1986; Aristov 1994; Leven et al. 1996). In the following, an attempt will be made to show the intensity of the mid-Artinskian extinction.

Rugose corals. The pre-crisis rugose coral assemblage shows a gradual taxonomic and quantitative decrease in genera and species of the widespread family Durhaminidae. This phenomenon was typical of the climax phase of the Protolonsdaleiastraea ecological succession (Kossovaya 1997). The abovementioned family is specific to reefs, reef slopes, and buildups of the Asselian, Sakmarian, and Early Artinskian age.

Just before the Parafusulina solidissima fusulinid Zone (= Bairdia aculeata ostracode Zone) the final disappearance of most of the fasciculate and massive colonial Rugosa, as well as the solitary corals with dissepiments, takes place.

Following the crisis, the assemblage of the rugose corals (type I of holdovers) reappears at the beginning of the Late Artinskian. It consists of simple primitive ahermatypic diaphragmatophoral corals, the so-called Cyathaxonia fauna, and is represented in the sections studied by solitary corals bearing axial structures of different types (Flügel 1972, 1973). Among these a pseudoseptal columella (Cyathaxonia and Cyathocarinia), septa-formed columella (Pseudowannerophyllum and Verbeekiella), and septal column (Lophophyllidium (Lophbillidium)) (coral assemblage I, Fig. 6) should be noted. In some cases, the pseudoaxial structure formed from the parts of septa existed for a rather long time in the neanic stage, but not until the maturity stage (Paralleynia type). The corals identified in the Most and Karpikha sections include Lophophyllidium (Lophbillidium) magnocolumnare Fedor., Pseudowannerophyllum sp. 1, Cyathaxonia ex gr. C. cornu Mich., Cyathocarinia multituberculata Soshk., Paralleynia permiana Soshk., Ufimia carbonaria Stuck., Ufimia sp. nov. 1, Soshkineophyllum artiense (Soshk.), and Verbeekiella sp. All together 15 species from 10 genera were identified; most of them were immigrants. Most probably, this assemblage inhabited deep-water facies (Flügel 1973; Kullmann 1997) in the northern, central, and southern parts of the Urals (see fauna lists in Sochkine 1925; Soschkina 1928; Soshkina 1932; Soshkina et al. 1941; Simakova 1986). 


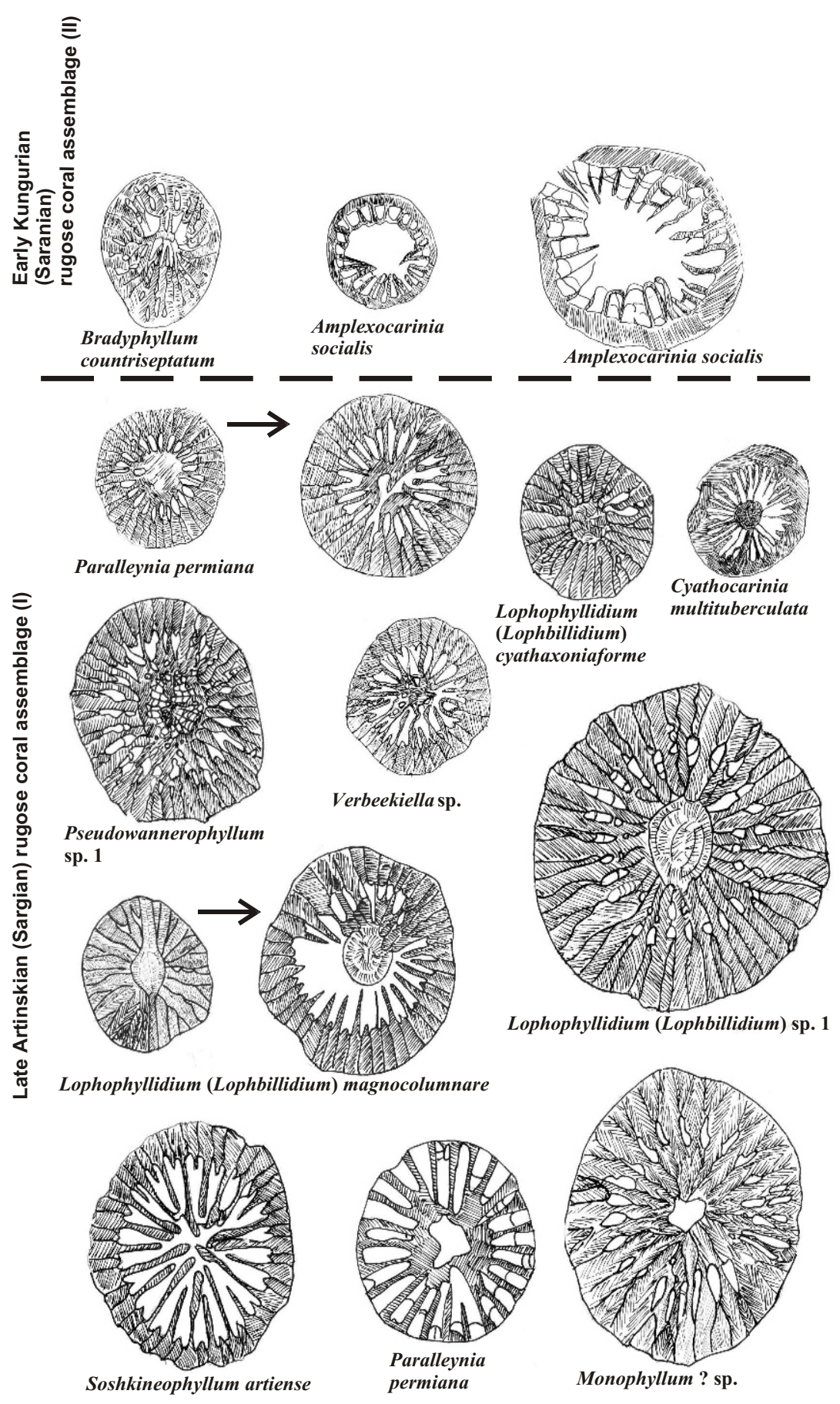

Fig. 6. Lowermost Late Artinskian deep cool-water assemblage (I) and lowermost Kungurian warm-water assemblage (II). 
Further changes in the taxonomic composition of the holdover assemblage (coral assemblage II, Fig. 6) occurred in the Early Kungurian. Only three genera survived: Bradyphyllum countriseptatum, Br. aff. Br. postwannense, Amplexocarinia socialis, and Euryphyllium sp. All of them had a pseudoaxial structure in the early stage of ontogeny. This assemblage occupied the Early Kungurian restricted basins, and thus morphological changes in it coincided with the increase in water temperature. The preliminary isotopic data show the fall of the ${ }^{18} \mathrm{O} /{ }^{17} \mathrm{O}$ ratio in the Sula River section at this level.

Fusulinids. The fusulinids of the western and eastern Pangea marginal basins are very much alike. Their impoverished community is represented by the Pseudoschwagerina-Paraschwagerina assemblage in the western part and by the Praeparafusulina-Parafusulina assemblage in the eastern part of Pangea. The beginning of Yachtash time (Tethys realm), corresponding approximately to the beginning of the Artinskian, shows taxonomic diversification (Leven et al. 1996).

Ammonoids. Abrupt diversification of species and genera occurred in the middle of the Artinskian (Bogoslovskaya 1986). The lower Artinskian Substage (Aktastian Regional Substage) was marked by the appearance of Eothinitidae (Eothinites), Aktubinskia, Artioceras, Daraelites, and Neoshumardites. The Late Artinskian ammonoid assemblage includes Propinacoceras, Waagenina, Neocrimites, and diverse Uraloceras and Paragastrioceras (Bogoslovskaya 1986; Leven et al. 1996).

Conodonts. A well-known Early Permian crisis among conodonts (Ritter 1987; Aristov 1994) continues from the end of the Sakmarian to the middle of the Artinskian. The mid-Artinskian event coincides with the final phase of the conodont crisis and leads to ultimate extinction of the last typically Carboniferous taxa: Adetognathus lautus Gunnel, Streptognathodus elongatus Gunnel, and Streptognathodus artinskensis (Kozur \& Movshovitch). At the same time, it could have triggered the radiation within the Sweetognathus-Neostreptognathodus and neogondolellid lineages. The crisis association consisted of the tolerant and nonspecialized species such as Sweetognathus whitei (Rhodes) and Mesogondolella bisseli (Clark \& Behnken).

Late Artinskian time shows the diversification of species and appearance of Pseudosweetognathus, Rabeignathus, and Vjalovognathus (Leven et al. 1996).

Ostracodes. The Late Artinskian ostracode assemblage consists of 43 species of 14 genera. Among them, 31 species appear for the first time. Most of them are characteristic of the Bairdia aculeata ostracode Zone of the Sargian Substage (Gorsky et al. 1984). This association is followed by a much more diverse one, which seems to be evidence of the emergence of the Kungurian ostracode assemblage (the base of the Bairdia reussiana ostracode Zone; Fig. 4).

Flora. The middle of the Lower Permian is characterized by the immigration of the cordaite flora into the Subangarian regions (the Urals and Central Kazakhstan), as a response to temperature gradient decrease (Durante 1994). 


\section{CORRELATION}

In a few regions along the Pangea marginal shelves the event level seems to have valuable correlation potential. The main diagnostic features include coral fauna turnover, change in biota composition and facies, and the small isotopic shift. Besides the eastern shelf basins of Pangea (Central Urals, northern Timan), the event level has been identified in the Aidaralash Creek section (Southern Urals), where it coincides with the Aktastian-Baigendzhinian boundary (Davydov et al. 1997).

The last massive colonial corals of Durhaminidae and some other families were found in Spitsbergen in the Sakmarian Tyrellfjellet Formation (? Limestone B). The predominance of the bun-shaped cerioid rugose coral colonies points to relatively quiet-water subtidal and open-marine shelf environments (Somerville 1997). This facies and the coral composition are close to the Sakmarian ones (possibly Tastubian) of the western Urals and northern Timan. Contemporaneous early Artinskian deposits of the lowermost part of the Gipshuken Formation are represented by gypsum-anhydrite intercalating with dolomite and marls. Oolite limestone or dolomite beds occur as well. These sediments are interpreted as deposited in the restricted marine environment (Nakamura 1992).

The beginning of the next transgressive sedimentation cycle in the uppermost Lower Artinskian could be correlated with the upper part of the Gipshuken Formation, where brachiopods (in situ), bryozoans, and sponge spicules give evidence of open marine influx of temperate water conditions (Ezaki \& Kawamura 1992). The lower Sargian boundary (event level) can be indentified somewhere within the uppermost Gipshuken Formation (Fig. 5). Based on the appearance of shallower-water corals, Coral Unit 1 of the Kapp Starostin Formation, Festningen, Spitsbergen (Ezaki \& Kawamura 1992; Ezaki 1997), coincides with the Saranian impoverished coral assemblage of the beds with Amplexocarinia socialis.

In the Sverdrup Basin (Canada), the event level may be established at the lower boundary of the Great Bear Cape Formation based on the biotic change. The Great Bear Cape Formation contains bryozoans, echinoderms, and brachiopods, which are associated with locally abundant fusulinaceans and colonial rugose corals. This biota, referred to as a Bryonoderm-extended assemblage, indicates much colder temperate conditions than those evidenced by the abundant algae and foraminifers (Chloroforam assemblage) of the older Raanes Formation and Belcher Channel Formation. The rocks of the Great Bear Cape Formation are interpreted as tempestites, formed in the high-energy environments on an open, wave-swept shelf (Beauchamp \& Theriault 1994).

As a whole, the coral fauna of the Sakmarian-Artinskian (Lower Artinskian ?) deposits of the Sverdrup Basin includes Heritschioides, Kleopatrina, Protolonsdaleiastraea, and Stylastraea (Gunning et al. 1994). These genera are widespread in the coeval deposits of the Urals, Volga-Urals region, and northern Timan (Soshkina et al. 1941; Kossovaya 1996). 
The mid-Artinskian event is less reflected in the Ambition Formation in northwestern Stikina, British Columbia, where more abundant fasciculate (morphoecotype III) and solitary corals (morphoecotype II) were found together with Neostreptognathodus pequopensis (Gunning et al. 1994). This interval correlates with the upper part of the Sargian Substage (Fig. 5). Also, a weak reflection of the event is seen in the coeval deposits of Nevada, where the massive colonial corals Kleopatrina (Porfirievella) illipahensis (Easton) and Permastraea (?) hudsoni (Wils. \& Long.) were found in the Pequop Formation, Nevada (Stevens 1967). The latter could be correlated with the upper Sargian Substage based on the occurrence of Neostreptognathodus pequopensis (Behnken 1975). The underlying deposits, containing Kleopatrina (K.) arcturensis Stevens and Durhamina cordillerensis (Easton), have been assigned to the upper part of the Mesogondolella bisseli-Sweetognathus whitei Zone (Ritter 1987). They may be preliminarily correlated with the lower part of Sargian Substage. Massive colonial corals disappeared in this area in Late Leonardian time (Stevens 1967).

The occurrence of similar rugose coral species Lophophyllidium (Lophbillidium) magnocolumnare (Fedor.) and Lophophyllidium (L.) cyathaxoniformis Fedor. (Fedorowski 1987) permits us to correlate the Sargian Substage with the Lower Bone Spring Formation (Upper Leonardian, Texas), the Bitauni Beds of Timor (Schindewolf 1942; Schouppe and Stacul 1955; Fedorowski 1986b), and the Lower Permian Calceolispongia Stage of Australia (Hill 1942).

We can suggest that in the temperate belt of the eastern and northern shelves of Pangea fauna displays a stronger influence of the temperature decline (Urals, Canadian Arctic (part), Spitsbergen). In the tropical belt of the western shelf of Pangea (Nevada, Utah), the crisis is reflected in the moderate decrease in biodiversity only in comparison with the temperate belt.

\section{CONCLUSIONS}

The mid-Artinskian biotic event is characterized by an abrupt coral turnover. The Early Artinskian pre-event assemblage corresponds to the elimination phase of massive colonial corals. The Upper Artinskian post-event assemblage is characterized by the appearance of the opportunistic taxa (holdovers) consisting of small primitive corals. This crisis is accompanied by remarkable changes in the other groups of fauna.

The following causes of the biota turnover may be suggested:

1. The beginning of the transgression led to gradual replacement of the Palaeoaplysina-coral-fusulinid association by the bryozoan-spicules-ostracode association. A specific ecological community appeared at the maximum flooding surface. This community was represented by sponges with monaxon spicules, ostracodes, and small solitary corals, considered as post-crisis holdovers. One of the possible reasons for cooling could be the influx of cold oceanic water 
carried by oceanic currents (Beauchamp et al. 1987). The influence of cold water decreased towards the inner part of the remaining Uralian Ocean.

2. The taxonomic composition of this assemblage reflects the temperature decrease, determined in reference sections of the northern Timan and western Urals. Coeval temperature fall was also recognized in the uppermost part of the Gipshuken Formation of West Spitsbergen and approximately contemporaneous deposits of the Sverdrup Basin of the Canadian Arctic (Beauchamp at al. 1987; Beauchamp \& Theriault 1994).

It seems that the area of the mid-Artinskian ecological event is restricted by western (partly), northern, and eastern marginal basins of Pangea. The geographical extension of the event is estimated as provincial or subglobal. The combination of similar abiotic and biotic features raises the potential of the Lower and Upper Artinskian boundary for interregional correlation.

\section{ACKNOWLEDGEMENTS}

The authors are grateful to V. Gorsky (VSEGEI, Russia) for advice in regional geology. We thank I. Somerville (Ireland) for revising the manuscript and improving English, and T. N. Koren (VSEGEI, Russia) for critical review. O. Kossovaya extends her thanks to the Organising Committee of the IGCP Project 335 "Biotic recoveries from mass extinction" for financial support for her visit to the Washington meeting and the American Museum of Natural History where she could study the rugose coral collections. Also, we are very grateful to the Peritethys Project No. 343 (led by A. Izart, France) and the American Paleontological Society PalSIRP Grant for financing this research. The present research was partly supported by the Russian Foundation for fundamental investigations (grants Nos. 96-05-65-758, 99-05-65290, 99-05-65140) and the Federal Programme "Integration".

\section{REFERENCES}

Antsygin, N. Ya., Popov, V. A. \& Chuvashov, B. I. (eds.). 1993. Stratigraficheskie skhemy Urala. IGIG INTs RAN, Ekaterinburg (in Russian).

Aristov, V. A. 1994. Devonian and Lower Carboniferous conodonts of the Eurasia: Assemblages, zonal subdivisions, correlation of different facies sediments (Gladenkov, Yu. B., ed.). Tr. GIN RAN, 484 (in Russian).

Barkhatova, V. P. 1970. Biostratigraphy of the Carboniferous and Permian Deposits of the Northern Timan. Nedra, Leningrad (in Russian).

Beauchamp, B. \& Theriault, P. 1994. Late Paleozoic syn- and post-rift sequences on Grinnell Peninsula, Canadian Arctic (Sverdrup Basin): evidence for basin margin tectonic disturbances associated with sequence boundaries. In Pangea: Global Environments and Resources. Can. Soc. Petrol. Geol. Mem., 17, 199-217.

Beauchamp, B., Oldershaw, A. E. \& Krouse, H. R. 1987. Upper Carboniferous to Upper Permian ${ }^{13} \mathrm{C}$-enriched primary carbonates in the Sverdrup basin, Canadian Arctic: comparison to coeval Western-North American ocean margin. Chem. Geol., 65, 391-413. 
Beauchamp, B., Harrison, J. C. \& Henderson, C. M. 1989. Upper Paleozoic stratigraphy and basin analysis of the Sverdrup Basin, Canadian Arctic Archipelago: Part 2, transgressiveregressive sequences. In Contribution to Frontier Geoscience Program, Current Research, Part G. Geol. Surv. Canada, 89-1 G, 115-124.

Behnken, F. H. 1975. Leonardian and Guadalupian (Permian) conodont biostratigraphy in western and south-western United States. J. Paleont., 49, 284-315.

Bogoslovskaya, M. F. 1986. Ammonoids. In Atlas kharakternykh kompleksov permskoj fauny i flory Urala i Russkoj Platformy (Gorsky, V. P. \& Kalmykova, M. A, eds.). Tr. VSEGEI, Novaya Seriya, 331, 14-15 (in Russian).

Chuvashov, B. I. 1997. Kungurian Stage of the Permian System (problem of determination and correlation). Strat. Geol. Correlation, 5, 10-28 (in Russian).

Chuvashov, B. I. \& Nairn, A. E. M. (eds.). 1993. Permian System: guides to geological excursions in the Uralian type localities. Occasional Publ. ESRI, New Ser., 10.

Chuvashov, B. I., Foster, C. B., Mizens, G. A., Roberts, J. \& Claoue-Long, J. C. 1996. Radiometric (Shrimp) dates for some biostratigraphic horizons and event levels from the Russian and Eastern Australian Upper Carboniferous and Permian. Permophiles, 28, 29-36.

Davydov, V. I., Snyider, W. S. \& Spinosa, C. 1997. Upper Paleozoic Fusulinacean biostratigraphy of the Southern Urals. Permophiles, 30, 11-14.

Durante, M. V. 1994. Upper Paleozoic floras of Angarland palaeoecosystematic approach (climatic reconstruction). In Ecosystem Restructures and the Evolution of Biosphere, 1 (Rozanov, A. Yu. \& Semikhatov, M. A., eds.), pp. 248-258. Nedra, Moscow (in Russian).

Ezaki, Y. 1997. Cold-water Permian Rugosa and their extinction in Spitsbergen. Bol. R. Soc. Esp. Hist. Nat. Sec. Geol., 92, 381-388.

Ezaki, Y. \& Kawamura, T. 1992. Carboniferous-Permian corals from Skansen and Festningen, Central Spitsbergen: their faunal characteristics. In Investigation on the CarboniferousUpper Permian Succession of West Spitsbergen 1989-1991 by Japanese-Norwegian Research Group (Nakamura, K., ed.), pp. 59-75. Hokkaido Univ., Sapporo.

Fedorowski, J. 1986a. The rugose coral faunas of the Carboniferous/Permian boundary interval. Acta Palaeont. Pol., 31, 253-275.

Fedorowski, J. 1986b. Permian rugose corals from Timor (remarks on Schouppe \& Stacul collections and publications from 1955 and 1959). Palaeontographica A, 191, 173-226.

Fedorowski, J. 1987. Upper Palaeozoic rugose corals from Southwestern Texas and adjacent areas; Gaptank Formation and Wolfcampian corals, Part I. Palaeont. Polonica, 48.

Flügel, H. W. 1972. Die paläeozoischen Korallenfaunen Ost-Irans, 2: Rugosa und Tabulata der Jamal Formation (Darwasian?, Perm). Jahrb. Geol. B.-A., 115, 49-102.

Flügel, H. W. 1973. Rugose Korallen aus dem oberen Perm Ost-Grönlands. Verh. Geol. B.-A., 1.

Goreva, N. V., Kashik, D. S., Kossovaya, O. L., Lozkina, N. V., Miklukho-Maclay, O. A., Molchanova, L. M. \& Shafranovsky, G. I. 1997. Carboniferous and Permian key sections of the Northern Timan (Kashik, D. S., ed.). Trans. ISC, 24.

Gorsky, V. P., Alekseeva, I. A., Vladimirovich, V. P., Guseva, E. A., Kalmykova, M. A., Kashevarova, N. P. \& Faddeeva, I. Z. 1984. Eastern-European province. In Main Features of Stratigraphy of the Permian System in the USSR (Kotlyar, G. V. \& Stepanov, D. L., eds.). Tr. VSEGEI, Novaya Seriya, 286, 29-74.

Gunning, M. H., Bamber, E. W., Brown, D. A., Rui, L., Mamet, B. L. \& Orchard, M. J. 1994. The Permian Ambition Formation of Northwestern Stikinia, British Columbia. In Pangea: Global Environments and Resources. Can. Soc. Petrol. Geol. Mem., 17, 589-619.

Hill, D. 1942. Further Permian corals from Western Australia. J. Roy. Soc. Western Australia, 27, $57-72$.

Keilen, H. B. 1992. Lower Permian sedimentary sequences in Central Spitsbergen, Svalbard. In Investigation on the Carboniferous-Upper Permian Succession of West Spitsbergen 1989-1991 by Japanese-Norwegian Research Group (Nakamura, K., ed.), pp. 127-134. Hokkaido Univ., Sapporo. 
Kossovaya, O. L. 1993. Some aspects of the study of massive Durhaminidae. Cour. Forsch-inst. Senckenberg, 164, 89-101.

Kossovaya, O. L. 1994. Dynamics of the rugose extinction in the Urals Cordillera Arctic region (Early Permian). In Ecosystem Restructures and the Evolution of Biosphere, Vol. 1 (Rozanov, A. Yu. \& Semikhatov, M. A., eds.), pp. 126-132. Nedra, Moscow (in Russian).

Kossovaya, O. L. 1996. Correlation of Uppermost Carboniferous and Lower Permian rugose coral zones from the Urals to Western North America. Palaios, 11, 71-82.

Kossovaya, O. L. 1997. Upper Carboniferous-Lower Permian rugose corals of the Urals and northern Timan. In Atlas etalonnykh kompleksov paleozojskoj bentosnoj fauny severovostoka evropejskoj Rossii: (ostrakody, brakhiopody, rugozy) (Stukalina, G. A.,, ed.), pp. 53-96. VSEGEI, St. Petersburg (in Russian).

Kullmann, J. 1997. Rugose corals in non-reef environments - the case of the "Cyathaxonia fauna". Bol. R. Soc. Esp. Hist. Nat. Sec. Geol., 92, 187-195.

Leven, E. Ya., $\quad$ Bogoslovskaya, M. F., Ganelin, V. G., $\quad$ Grunt, T. A., $\quad$ Leonova, T. B. \& Reimers, A. N. 1996. Reorganization of marine Biota during the Mid-Early Permian Epoch. Strat. Geol. Correl., 4, 61-70.

Malkowski, K. \& Szaniawski, H. 1975. Permian conodonts from Spitsbergen and their stratigraphic significance: a preliminary note. Norsk Polarinst. Arbok, 79-87.

Nakamura, K. (ed.). 1992. Investigation on the Carboniferous-Upper Permian Succession of West Spitsbergen 1989-1991 by Japanese-Norwegian Research Group. Hokkaido Univ., Sapporo.

Pnev, V. P. 1974. Karpikha section. In Putevoditel' ékskursii po nizhnepermskim otlozheniyam po rekam Kosve, Sylve i Kame. Permskaya oblast' (Safronitskij, P. A., ed.), pp. 57-58. Perm (in Russian).

Ritter, S. M. 1987. Biofacies-based refinement of Early Permian conodont biostratigraphy in central and western USA. In Conodont Investigation Techniques and Applications (Aldridge, R. J., ed.), pp. 383-403. Ellis Horwood, Chichester.

Schindewolf, O. H. 1942. Zur Kenntnis der Polycoelien und Plerophyllen. Abh. Reichs. Bodenforsch (n.F.), 204.

Schouppe, A. \& Stacul, P. 1955. Verbeekiella Penecke, Timorphyllum Gerth, Wannerophyllum n. gen., Lophophyllidium Grabau aus dem Perm von Timor. Palaeontographica, Suppl. IV, pt. V, 95-196.

Simakova, M. A. 1986. Tetracoralla - Rugosa. In Atlas kharakternykh kompleksov permskoj fauny $i$ flory Urala i Russkoj Platformy (Gorsky, V. P. \& Kalmykova, M. A, eds.). Tr. VSEGEI, Novaya Seriya, 331, 11-12 (in Russian).

Somerville, I. D. 1997. Biostratigraphy and biofacies of Upper Carboniferous-Lower Permian rugose assemblages from the Isfjorden area, central Spitsbergen. Bol. R. Soc. Esp. Hist. Nat. Sec. Geol., 92, 365-380.

Sochkine, E. 1925. Les coraux du Permien inferieur (etage d'Artinsk) du versant occidental de l'Oural. Bull. Soc. Nat. Moscow Geol., 11, 76-109.

Soschkina, E. 1928. Die interpermischen Korallen dem westlichen Abhang des nordlichen Uralgebirges. Bull. MOIP Geol., 4, 337-393.

Soshkina, E. D. 1932. Lower Permian (Artinskian) corals of the Ufimian plateau. Bull. MOIP Geol., 10, 251-267 (in Russian).

Soshkina, E., Dobrolyubova, T. \& Porfiriev, G. 1941. The Permian Rugose corals of the European Part of the USSR. In Paleontology of USSR, 5, pt. 3, fasc. 1.

Stevens, C. H. 1967. Leonardian (Permian) compound corals of Nevada. J. Paleont., 41, 423-431.

Waterhouse, J. B. 1997. The Permian time-scale. Permophiles, 30, 6-8.

Wilson, J. L. 1980. Carbonate Facies in the Geological History. Nedra, Moscow (in Russian). 


\title{
KESK-ARTINSKI (VARA-PERMI) ÖKOLOOGILISE SÜNDMUSE UURING UURALI JA PÕHJA-TIMAANI LÄBILÕIGETES
}

\author{
Olga L. KOSSOVAJA, Ekaterina A. GUSEVA, Aleksander E. LUKIN ja \\ Andrei V. ŽURAVLEV
}

On uuritud biootilisi ja abiootilisi muutusi, mis ilmnesid reas Kesk-Artinski vanusega kivimite läbilõigetes Põhja-Timaanil ja Kesk-Uurali läänenõlval. Esmakordselt on kirjeldatud korallide levikut, elustiku terviklikku taksonoomilist koostist, paleotemperatuuri ja mikrofaatsieste muutusi. Stratigraafiliste tasemete määrangute aluseks on võetud uued ja revideeritud biostratigraafilised andmed. Temperatuuri langus Kesk-Artinski eal korreleerub mere maksimaalse transgressiooni tasemega ning seda käsitletakse põhjusena, mis algatas paljude faunarühmade koosseisu muutumise ja/või väljasuremise. See ökoloogilise sündmuse tase tuvastati ka Pangea šelfi samaealistes settekivimites.

\section{СРЕДНЕАРТИНСКОЕ (РАННЯЯ ПЕРМЬ) ЭКОЛОГИЧЕСКОЕ СОБЫТИЕ НА ПРИМЕРЕ УРАЛА И СЕВЕРНОГО ТИМАНА}

\author{
Ольга Л. КОССОВАЯ, Екатерина А. ГУСЕВА, Александр Е. ЛУКИН и \\ Андрей В. ЖУРАВЛЕВ
}

Рассмотрены биотические и абиотические изменения в середине артинского века на примере ряда конкретных разрезов Северного Тимана и западного склона Среднего Урала.

Данные по стратиграфическому распределению кораллов, изменению состава биоты, изменениям палеотемпературы и микрофаций получены впервые. Установленное понижение палеотемпературы совпадает с максимальным углублением бассейна (поверхностью максимального затопления) и рассматривается как возможная причина экологического события, вызвавшего перестройку или вымирание многих фаунистических групп. Событийный уровень был распознан в одновозрастных отложениях шельфов Пангеи. 